\title{
Laccases for Denim Bleaching: An Eco-Friendly Alternative
}

\author{
S. Rodríguez-Couto ${ }^{*}, 1,2$ \\ ${ }^{I}$ CEIT, Unit of Environmental Engineering, Paseo Manuel de Lardizábal 15, 20018, San Sebastian, Spain \\ ${ }^{2}$ IKERBASQUE, Basque Foundation for Science, Alameda de Urquijo 36, 48011, Bilbao, Spain
}

\begin{abstract}
Laccases have received much attention of researchers in last decades due to their ability to oxidise both phenolic and non-phenolic lignin-related compounds as well as highly recalcitrant environmental pollutants which makes them very useful for their application to several biotechnological processes such as those from the textile industry. In this regard, laccases are used for denim bleaching as an alternative to the hazardous and non-environmentally friendly chemical process. Thus, the first commercial laccase preparation was introduced in 1996 as liquid slurry. The product exhibited good performance, but handling characteristics were not ideal. A fully-formulated solid laccase has been commercially available for the denim market since 1999. Today, customised formulations of laccase are routinely used to target specific garment wet process conditions.
\end{abstract}

Keywords: Laccase, denim, bleaching, textile industry.

\section{INTRODUCTION}

Yoshida [1] first described laccase in 1883 when he extracted it from the exudates of the Japanese lacquer tree Rhus vernicifera, from which the name laccase was derived and was characterised as a metal-containing oxidase by Bertrand [2]. This makes laccase one of the oldest enzymes ever described. Laccases have also been detected in insects [3] and bacteria [4] but they are especially abundant in white-rot fungi, which are the only microorganisms able to degrade the whole wood components. Laccases (EC 1.10.3.2, p-diphenol oxidases) are copper-containing enzymes that catalyse the oxidation of a wide variety of organic and inorganic substrates, including mono-, di-, and polyphenols, amino phenols, methoxy phenols, aromatic amines and ascorbate with the concomitant four electron reduction of oxygen to water [5-8]. Laccases contain one type 1 (T1) $\mathrm{Cu}$ centre, one type 2 (T2) $\mathrm{Cu}$ centre and one type 3 (T3) $\mathrm{Cu}$ centre. The T2 and T3 sites form a trinuclear $\mathrm{Cu}$ cluster onto which $\mathrm{O}_{2}$ is reduced. The $\mathrm{T} 1 \mathrm{Cu}$ oxidises the reducing substrate and transfers electrons to the $\mathrm{T} 2$ and $\mathrm{T} 3$ $\mathrm{Cu}$ (Fig. 1).

Laccases have relatively lower redox potentials $(0.45$ $0.80 \mathrm{~V}$ versus the normal hydrogen electrode) than those of ligninolytic peroxidases $(>1 \mathrm{~V})$, so it was initially thought that laccases were only able to oxidise phenolic substrates [10]. However, the range of substrates oxidised by laccases can be increased through a mediator-involved reaction mechanism. Redox mediators are low-molecular weight compounds that are easily oxidised by laccases producing, in some cases, very unstable and reactive cationic radicals, which can oxidise more complex substrates before returning to their original state. The electrons taken by laccases are finally transferred back to oxygen to form water $[11,12]$.

*Address correspondence to this author at the CEIT, Unit of Environmental Engineering, Paseo Manuel de Lardizábal 15, 20018 San Sebastian, Spain; Tel: +34 943212800 (Ext. 2239); Fax: +34 943 213076;

E-mail: srodriguez@ceit.es

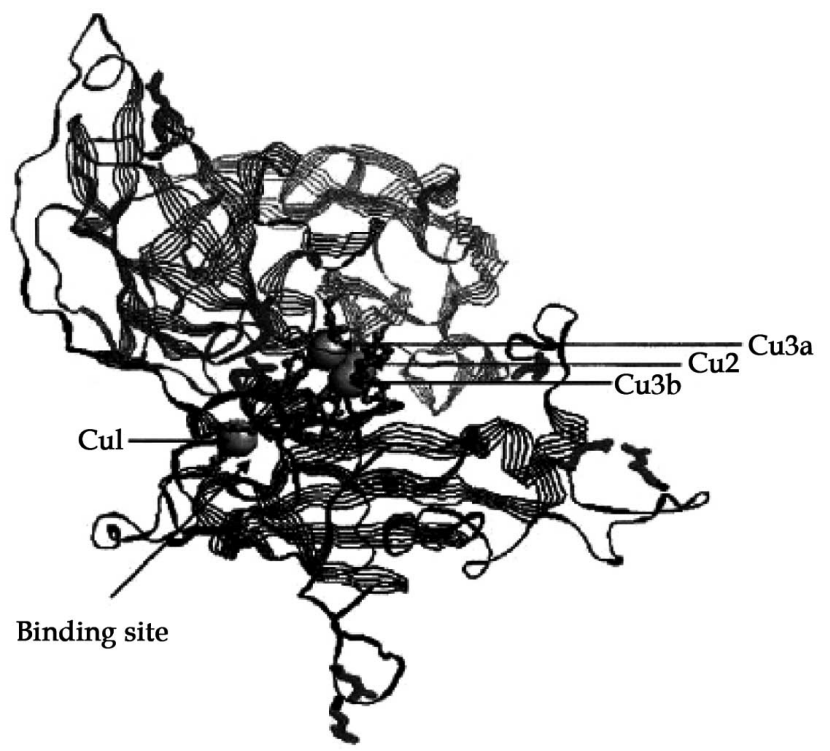

Fig. (1). Three dimensional structure of laccase from Rhus vernicifera. There are three cuprodoxin-like domains: the T1 site (Cu1) belongs to domain 3 and the T2/T3 site $(\mathrm{Cu} 2, \mathrm{Cu} 3 \mathrm{a}$ and $\mathrm{Cu} 3 \mathrm{~b}$ ) is the interface between the two other domains. The model also indicates the putative binding sites for glutaraldheyde. (Figure re-printed from Durante et al., (2004) Journal of Molecular Catalysis B: Enzymatic 27, 191-206 [9], with kind permission of Elsevier Ltd.).

Fig. (2) shows a schematic representation of laccasecatalysed redox cycles for substrate oxidation in the absence (A) or in the presence (B) of redox mediators [13]. The chemical structure of the most frequently-used synthetic mediators is depicted in Fig. (3). The laccase mediator system (LMS) has been shown to be efficient in the degradation of aromatic contaminants [14], paper pulp bleaching [15], pitch control [16] and dye decolouration [17]. An LMS process has been introduced in the textile industry for indigo oxidation on denim garments in industrial 


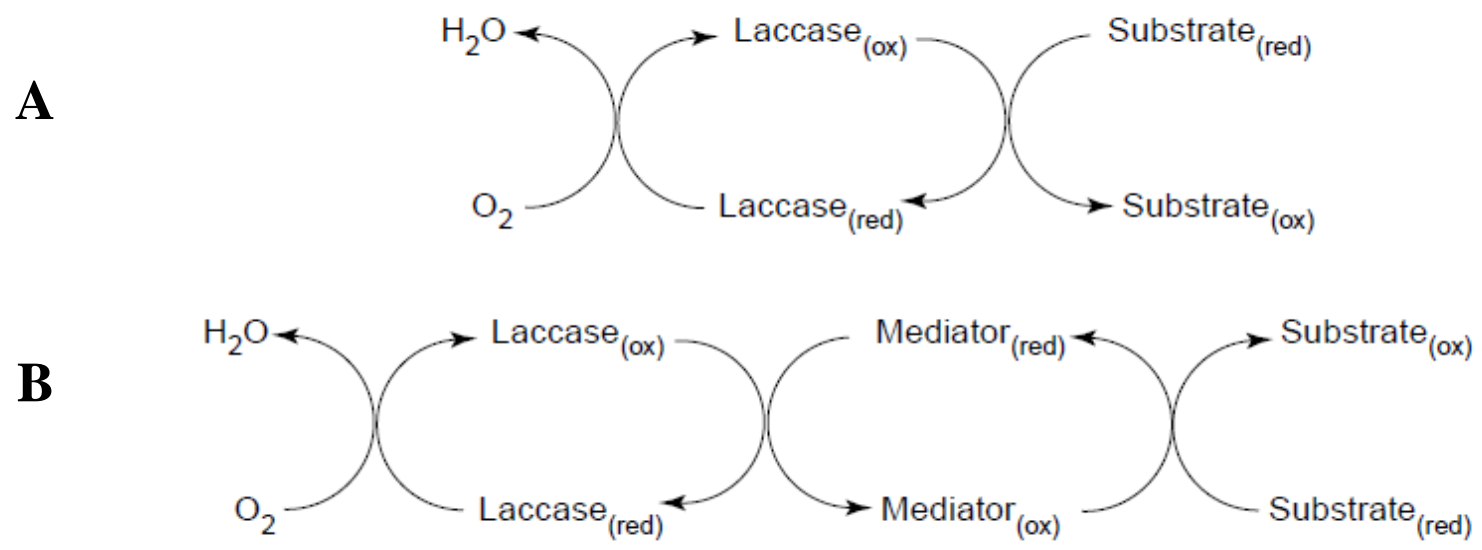

Fig. (2). Schematic representation of laccase-catalysed redox cycles for substrates oxidation in the absence (A) or in the presence (B) of redox mediators (Figure re-printed from Riva (2006) Trends Biotechnol 24, 219-226 [13], with kind permission of Elsevier Ltd.).<smiles>On1nnc2ccccc21</smiles>

A<smiles>O=C1NC(=O)C(=NO)C(=O)N1</smiles>

B<smiles>CCn1c(=NN=c2sc3cc(S(=O)(=O)O)ccc3n2CC)sc2cc(S(=O)(=O)O)ccc21</smiles>

C<smiles>COc1ccc(CO)cc1OC</smiles>

D

Fig. (3). Chemical structures of the most frequently-used redox mediators: 1-hydroxybenzotriazole (A), violuric acid (B), 2,2-azinobis(3ethylbenzothiazoline-6-sulfonic acid) (ABTS) (C) and veratryl alcohol (D).

laundries-the dye chromophore is split to yield two molecules of uncoloured compounds [18]. Fig. (4) illustrates a possible mechanism for laccase catalysed degradation of indigo dye [19].

Several articles have reviewed the diverse potential applications of laccases [20, 21]. However, the current commercial price of laccases is high (Table 1) limiting their industrial exploitation. Thus, current research is focussing on cost-effectively production of laccases. Recently, Osma et al., [22] determined that the cost of the culture medium represented the highest contribution to the total cost of laccase production. Therefore, a good strategy to lower the cost of laccase production would be reducing the cost of the culture medium. For this a variety of agroindustrial residues as well as wastewater may be utilised [23].

\section{LACCASES IN DENIM BLEACHING}

The use of laccase in the textile industry is growing very fast, especially in bleaching processes where the use of
Table 1. Price of Some Commercially Available Laccases (Extracted from Osma et al., (2011) Journal of Environmental Management 92, 2907-2912 [22], with kind permission of Elsevier Ltd.)

\begin{tabular}{|c|c|c|}
\hline $\begin{array}{c}\text { Supplier / } \\
\text { Reference }\end{array}$ & Description & $\begin{array}{c}\text { Price } \\
{[\boldsymbol{\epsilon} / \mathbf{U}]}\end{array}$ \\
\hline \hline Sigma / L2157 & $\begin{array}{c}\text { Laccase from Rhus vernificera } \\
(>50 \text { units/mg) }\end{array}$ & $1.5 \times 10^{-2}$ \\
\hline Sigma / 53739 & $\begin{array}{c}\text { Laccase from Trametes versicolor }, \\
\text { BioChemika }(>20 \text { units } / \mathrm{mg})\end{array}$ & $0.4 \times 10^{-2}$ \\
\hline Sigma / 38429 & $\begin{array}{c}\text { Laccase from Trametes versicolor }, \\
\text { BioChemika }(\geq 0.5 \text { units/mg) }\end{array}$ & 0.076 \\
\hline $\begin{array}{c}\text { Jena } \\
\text { Bioscience/ } \\
\text { EN-204 }\end{array}$ & $\begin{array}{c}\text { Laccase EC } 1.10 .3 .2 \\
\text { from Trametes versicolor }\end{array}$ & 0.060 \\
\hline \multicolumn{2}{|c}{} \\
\hline
\end{tabular}

laccases for denim bleaching is outstanding. All over the world, light washes on blue denim jeans are mainly bleached 
<smiles>O=C1Nc2ccccc2C(=O)C1=C1Nc2ccccc2N1</smiles>

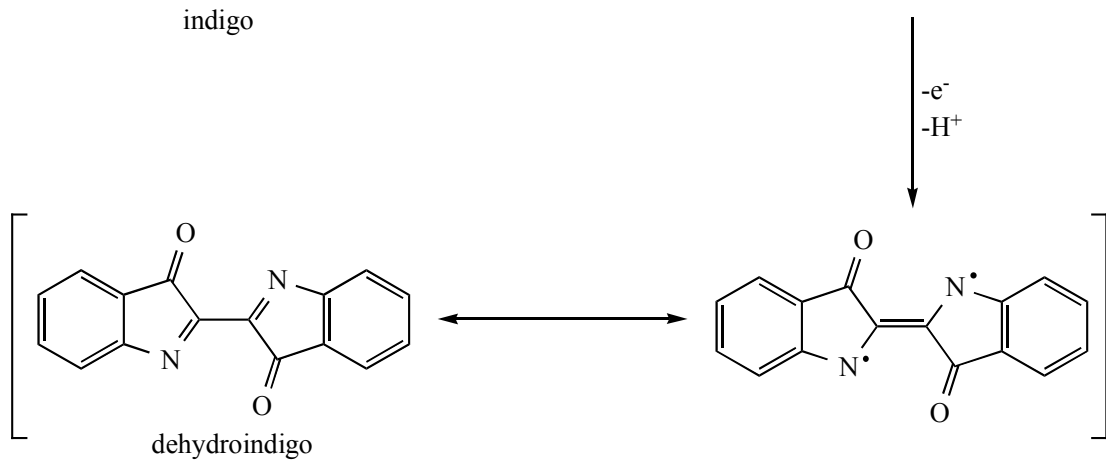<smiles>[Y][CH]C</smiles>

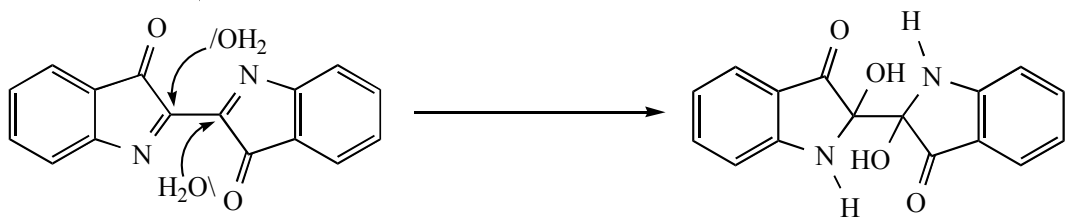

2<smiles>O=C1Nc2ccccc2C1=O</smiles><smiles>[3H]</smiles><smiles>O=C1NC(C(=O)O)(C23C[TlH]N(C2=O)c2ccccc2C3=O)c2ccccc21</smiles><smiles>Nc1ccccc1C(=O)C(=O)O</smiles>

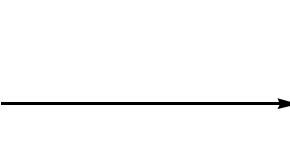<smiles>Nc1ccccc1C(=O)O</smiles>

anthranilic acid

Fig. (4). A possible mechanism for laccase-catalysed degradation of indigo dye (Figure re-printed from Campos et al., (2001) Journal of Biotechnology 89, 131-139 [19], with kind permission of Elsevier Ltd.).

with sodium hypochlorite. It has certain advantages of being cheap and the reaction takes place at room temperature, but it is also a harsh chemical and gives yellowness to the fabrics if not neutralised properly. Being a strong oxidising agent, it also attacks cotton and reduces its strength which is not desirable in light ounce denim. In addition, it cannot be used for Lycra-containing garments. Also, the hypochlorite process is environmentally very harmful both because chlorite itself is harmful and because the subsequent neutralisation step generates high amounts of salts leading to disposal and pollution problems such as increase in biological oxygen demand (BOD) and in chemical oxygen demand (COD) level in effluent with the subsequent increase of effluent processing cost. Nowadays people have become more environmental conscious and a trend of eco-friendly processing is becoming more and more popular. In addition, govern- 


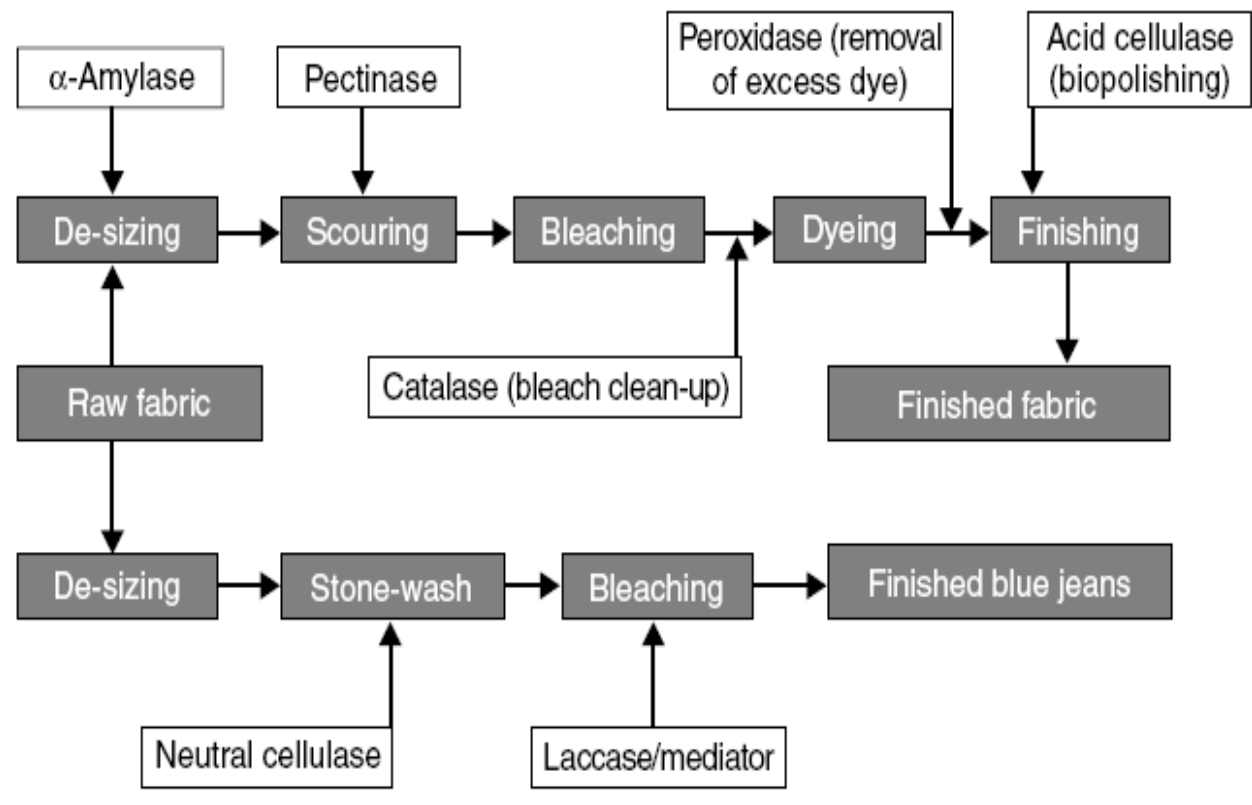

Fig. (5). Enzymes used in various unit operations in textile wet processing and the manufacturing of denim (Figure re-printed from Kirk et al., (2002) Current Opinion in Biotechnology 13, 345-351 [24], with kind permission of Elsevier Ltd.).

ment agencies are putting more restrictions for control on effluent quality. In these circumstances, processors are looking for an eco-friendly alternative. In denim garment processing, enzymes are used for desizing and abrasion look (Fig. 5). As being biodegradable enzymes are eco-friendly. Thus, laccases as bleaching agents for blue denim are an ecological alternative. In jeans bleaching laccases work exclusively on the indigo, with minimal fibre damage. The process is simple and easily reproducible.

The first commercial product based on laccase enzyme was launched in 1996 by Novozyme (Novo Nordisk, Denmark): Denilite $\mathrm{I}_{\mathrm{TM}}$, the first industrial laccase and the first bleaching enzyme acting with the help of a redox mediator molecule. The product exhibited good performance, but handling characteristics were not ideal. Thus, in 1999, Novozyme North America Inc. (USA) launched DeniLiteII $_{\mathrm{TM}}$ based on a new type of laccase with higher activity than that of Denilite $\mathrm{I}_{\mathrm{TM}}$. Later, in 2001, the company Zytex Pvt. Ltd. (India) developed a formulation based on LMS capable of degrading indigo in a very specific way. The trade name of the product is Zylite. Today, customised formulations of laccase are routinely used to target specific garment wet process conditions. Thus, the company Season Chemicals Dyestuffs Ltd. (Hong Kong) has launched a fullyformulated laccase enzyme preparation named Bleach-cut $3 \mathrm{~S}$. This preparation, containing laccase enzyme, redox mediator and buffer system, is extremely efficient in decolouration or bleaching of indigo. The treatment is typically carried out after biostoning with cellulase. By varying the dosage and/or treatment time, it is possible to obtain almost all shades, even the lightest ones. Bleach-cut $3 \mathrm{~S}$ treatment is an environmentally friendly method and easy to control. It does not affect harmfully on the strength of the fabric and is also suitable for denim containing Lycra or other elastic. Bleach-cut $3 \mathrm{~S}$ can also be used for clean-up of backstaining and enhancement of denim abrasion.
The company AB Enzymes GmbH (Germany) has commercialised a product called ECOSTONE ${ }^{\mathbb{B}}$ LCC 10, which oxidises the indigo dye with the help of a mediator radical (oxidising agent). This means that it can be used for the decolouration of indigo or bleaching of denim. Because it is easy to control, a variety of shades and looks can be obtained by changing the dosage or treatment time, even the lightest shades are possible. It has no adverse effects on the strength of denim containing Lycra or other elastic materials.

The company Puridet Asia Ltd. (Hong Kong) has launched a product named Purizyme consisting of laccase to be used in the bleaching of indigo-dyed garments. The advantages of such a product are that it is environmetally friendly, retains high fabric strength and enhances denim abrasion.

Apollo Chemical Company, LLC (USA) has comercialised a product named APCOZYME II-S, which is a prebuffered granulated laccase enzyme used to bleach or reduce the indigo dye on denim textiles. This product will preferentially break down the indigo molecule, leaving behind any sulfur or other dyes that might be present. There is a tendency to have a grayish or antique look, as opposed to the light blue cast normally associated with sodium hypochlorite bleaching.

Tri-Tex Co. Inc. (Canada) has developed a product named Trilite II, which is a granular laccase enzyme used for the decolouration of indigo dyes in denim wet processing applications. Trilite II gives a nice grey cast on denim jeans, compared to hypochlorite conventional bleach, at a minimum strength loss and is an ideal product for stretch jeans. The advantages of using this product are: improved shade reproduction, little effect on fabric strength, produces grey shade, functions at convenient $\mathrm{pH}$ and temperature and is very effective at rendering cellulase inactive. However, it has the following disadvantages: it is expensive compared to hypochlorite, it does not destroy sulfur black dye and 
requires oxygen to function. An extra powerful concentrated version is also available under the name of Trilite Plus.

Americos Industries Inc. (India) has developed two different commercial laccase preparations: Americos Laccase $\mathrm{P}$ and Americos Laccase LTC. Americos Laccase P does not attack the cellulose, so it is possible to get a "super stone wash" image on denim garments without typical breaks that normally occur after prolonged stone wash treatments with pumice stones and cellulase enzymes. In this case it is enough to execute a short cycle with Americos Laccase $\mathrm{P}$ after a standard stone wash. Another application in which Laccase P excels is the ecological bleach of denim garments. Americos Laccase P is virtually irreplaceable when the target is to conduct bleach on elasticised fabrics dyed with blue indigo. In this particular case, in fact, traditional bleach agents cannot be used since they would affect irreversibly the elasticity. Americos Laccase P affects selectively only the indigo dye, leaving unaltered the fibres regardless to their nature. Americos Laccase $\mathrm{P}$ is not compatible with cellulase enzymes making impossible its use in the stone wash bath. Anyway, it is possible to use Laccase $\mathrm{P}$ together with pumice stone. In this case the abrading effect is obtained in a mechanical way, while the enzymatic part of Laccase $P$ enhances the effect of the abrasion and leads simultaneously to a certain degree of decolouration. Americos Laccase LTC is a special mixture of active laccase enzyme and a control chemical mediator. The fungal laccase is specifically designed to be used for cleaning up back staining, changing colour shade and cast and to bleach denim. The chemical mediator assists the process in order to perform the full reaction chain which results in indigo bleaching. Americos Laccase LTC is specifically designed for the treatment of denim after stone washing to clean up back staining, enhance blue-white contrast, bleach elastic-containing garments and to adjust the shade and cast of the denim.

Hypozyme, commercialised by Condor Speciality Products (USA), is a laccase produced by fermentation of genetically-modified microorganisms. It is a product specially formulated to create a grey or deinking look to denim fabrics.

Lacasa Ultratex is a laccase preparation commercialised by Proenzimas Ltda. (Colombia) used for the decolouration of indigo in denim fabrics with slight effect on fabric resistance.

Cololacc BB is a laccase enzyme preparation launched by Colotex Biotechnology Co. Ltd. (Hong Kong) which is produced using a genetically-modified strain of non pathogenic fungi. It is used in denim finishing applications.

Novoprime $^{\circledR}$ Base 268 produced by Novozymes (Denmark) is a preparation based on a laccase produced by submerged fermentation of a genetically-modified microorganism. The enzyme protein, which in itself is not genetically modified, is separated and purified from the production organism.

Prozyme $^{\circledR}$ LAC developed by Sunson Industry Group Co. Ltd. (China) is a laccase designed specially to impart a bleaching effect on indigo denims with anti-back staining. It is an acid-stable enzyme, which acts on denims to aggravate the abrasion on indigo denims/dyed garments. It can be used directly or formulated as per the desired properties. It has the following advantages: grey shade change, creation of new looks, fashions, excellent backstaining removal after abrasion, enhances denim abrasion for reduced processing times, better strength retention of fabric, environmentally friendly and biodegradable. Prozyme ${ }^{\circledR}$ LAC is easily combined with most of denim finishing processes.

Lava $^{\circledR}$ Zyme LITE from DyStar GmbH (Germany) is a preparation of laccase plus a mediator which reduces the indigo to water-soluble decomposition products. Sulphur and reactive dyes are not affected by this bleaching system, since it is specific to indigo dye. This means that there is no attack to the cotton fibre and so nearly no loss in tensile strength.

Genencor International Inc. (USA), a division of Danisco (Denmark), launched in 2007 a new product line for the denim finishing market: IndiStar ${ }^{\mathrm{TM}}$ Color Adjust system. It consists of two components: IndiStar ${ }^{\mathrm{TM}}$ Active, a laccase enzyme and IndiStar ${ }^{\mathrm{TM}}$ Control, a denim bleaching mediator chemical. The IndiStar ${ }^{\mathrm{TM}}$ Color Adjust System offers denim processors the possibility to create new looks for denim whether the fashion demand is for increased contrast look or highly bleached worn vintage looks. The Genencor products are also gentle on elastic-incorporated garments. The IndiStar ${ }^{\mathrm{TM}}$ Active enzyme granules are manufactured with the proprietary Enzoguard ${ }^{\mathrm{TM}}$ granulation process developed by Genencor, which protects the enzyme from inactivation caused by exposure to oxygen and humidity. The IndiStar ${ }^{\mathrm{TM}}$ Control mediator molecule is a stable organic chemical which is not susceptible to degradation under normal storage conditions. IndiStar ${ }^{\mathrm{TM}}$ products can be used in a variety of conditions giving flexibility to choose the parameters most suitable for the needs of denim processors. With this product line, Genencor offers an environmentally friendly solution for replacement of harsh chemicals such as chlorine and permanganate. In 2009, the same company announced a new product, PrimaGreen EcoFade LT100, for the bleaching and dyeing of denim. This product contains a combination of laccase and a new type of mediator which make possible the creation of an entirely new look and at the same time it is environmentally friendly. The new technology is low energy and permits bleaching at neutral $\mathrm{pH}$ values and low temperatures, which means a reduction in the use of rinse water and neutralisation chemicals. Genencor believes the technology will allow textile producers to cut their heating energy for denim bleaching by up to $90 \%$.

Despite the increasing commercial preparations based on laccase enzyme for denim bleaching, there are few papers dealing with this topic. Campos et al., [19] reported the degradation of indigo both in effluents and on fabrics using purified laccases from Trametes hirsuta and Sclerotium rolfsii in combination with redox mediators and reported that bleaching of fabrics by laccases correlated with the release of indigo degradation products. Pazarlogliu et al., [25] showed that a phenol-induced laccase from Trametes versicolor was an effective agent for stone washing effects of denim fabric without using a mediator. Moreover, they found that $T$. versicolor laccase without a mediator was more effective than commercial laccase (obtained from recombinant Aspergillus niger, Novo Nordisk, Denmark) with a mediator. More recently, Solis-Oba et al., [26] applied the system laccase-ABTS to denim decolouration and found that such a process had the following advantages over the exisiting 
commercial processes: denim fibres were not attacked during decolouration, avoiding the use of stones will produce savings because machine life will be extended, cleaning expenses due to stone recovery will be eliminated, environmental impact will be reduced because the ABTS-laccase system will not produce halogenated byproducts and indigo oxidation byproducts will be easily biodegraded in either aerobic or anaerobic systems. Therefore, the residual wastewater treatment will be conducted in a simple way, reducing threats to the environment. Montazer and Maryan [27] reported a method based on laccases and cellulases for biowashing with a considerable reduction in consumption of laccases, cellulases, water, time and energy.

\section{FUTURE OUTLOOK}

Laccases are promising enzymes to replace the conventional chemical processes of the textile industry. However, one of the problems to commercialise the use of lacasse is the lack of capacity to produce sufficient enzyme stocks at low cost. Thus, efforts have to be made in order to achieve cheap overproduction of laccases in heterologous hosts and also their modification by chemical means or protein engineering to obtain more robust and active enzymes. Another additional problem is the cost and toxicity of redox mediators or their reaction products. Further investigations should consider different and less polluting mediators such as the natural mediators produced by laccase in a bioenvironment during lignin degradation. The availability of low cost and environmentally-friendly natural mediators could facilitate the application of LMS in industrial biotechnological processes. Another difficulty is the reuse of laccase, which could lower costs significantly. Immobilisation is a feasible method that would allow laccase reutilisation and self-immobilisation would further decrease costs as supports are not required.

In conclusion, laccases could be used in many different industrial applications. Whether such applications will become a reality it will depend on providing a cost-efficient method for laccase production and an effective method for laccase utilisation.

\section{CONFLICT OF INTEREST}

None declared.

\section{ACKNOWLEDGEMENTS}

The financial support of the Spanish Ministry of Science and Innovation (Project CTM2008-02453/TECNO) is gratefully acknowledged.

\section{REFERENCES}

[1] H. Yoshida, "Chemistry of lacquer (Urushi)", J. Chem. Soc., vol. 43, pp. 472-486, 1883.

[2] G. Bertrand, "Sur la laccase et sur le pouvoir oxydant de cette diastase", CR Acad. Sci. (Paris), vol. 120, pp. 266-269, 1895.

[3] S. Sidjanski, G.V. Mathews, and J.P. Vanderberg, "Electrophoretic separation and identification of phenol oxidases in hemolymph and midgut of adult Anopheles stephensi mosquitoes", J. Parasitol., vol. 83, pp. 686-691, 1997.
[4] G. Alexandre, and I.B. Zhulin, "Laccases are widespread in bacteria", Trends Biotechnol., vol. 18, pp. 41-42, 2000.

[5] B.R.M. Reinhammar, "Copper proteins and copper enzymes", CRC Press, Boca Raton, FL, 1984.

[6] C.F. Thurston, "The structure and function of fungal laccases", Microbiology, vol. 140, pp. 19-26, 1994.

[7] C. Eggert, U. Temp, and K.E.L. Eriksson, "Laccase-producing white-rot fungus lacking lignin peroxidase, and manganese peroxidase", ACS Symp. Ser., vol. 655, pp. 130-150, 1996.

[8] E.I. Solomon, U.M. Sundaram, and T.E. Machonkin, "Multicopper oxidases and oxygenases", Chem. Rev., vol. 96, pp. 2563-2605, 1996.

[9] D. Durante, R. Casadio, L. Martelli, G. Tasco, M. Portaccio, P. De Luca, U. Bencivenga, S. Rossi, S. Di Martino, V. Grano, N. Diano, and D.G. Mita, "Isothermal and non-isothermal bioreactors in the detoxification of waste waters polluted by aromatic compounds by means of immobilised laccase from Rhus vernicifera", J. Mol. Catal. B-Enzym., vol. 27, pp. 191-206, 2004.

[10] P.J. Kersten, B. Kalyanaraman, K. Hammel, B. Reinhammar, and T.K. Kirk, "Comparison of lignin peroxidase, horseradish peroxidase and laccase in the oxidation of methoxybenzenes", Biochem. J., vol. 268, pp. 475-480, 1990.

[11] M.A. McGuirl, and D.M. Dooley, "Copper-containing oxidases", Curr. Opin. Chem. Biol., vol. 3, pp. 138-144, 1999.

[12] Y. Wong, and J. Yu, "Laccase-catalyzed decolorization of synthetic dyes", Water Res., vol. 33, pp. 3512-3520, 1999.

[13] S. Riva, "Laccases: blue enzymes for green chemistry", Trends Biotechnol., vol. 24, pp. 219-226, 2006.

[14] P.J. Collins, M.J.J. Kotterman, J.A. Field, and A.D.W. Dobson "Oxidation of anthracene and benzo[a]pyrene by laccases from Trametes versicolor", Appl. Environ. Microbiol., vol. 62, pp. 45634567, 1996.

[15] S. Camarero, O. García, T. Vidal, J. Colom, J. C. del Río, A. Gutiérrez, J. M. Gras, R. Monje, M. J. Martínez, and A. T. Martínez, "Efficient bleaching of non-wood high-quality paper pulp using laccasemediator system", Enzyme Microb. Technol., vol. 35, pp. 113-120, 2004

[16] A. Gutiérrez, J. C. del Río, D. Ibarra, J. Rencoret, J. Romero, M. Speranza, S. Camarero, M. J. Martínez, and A. T. Martínez, "Enzymatic removal of free and conjugated sterols forming pitch deposits in environmentally sound bleaching of eucalypt paper pulp", Environ. Sci. Technol., vol. 40, pp. 3416-3422, 2006.

[17] M.R. Hu, Y.P. Chao, G.Q. Zhang, Z.Q. Xue, and S. Qian, "Laccase mediator system in the decolorization of different types of recalcitrant dyes", J. Ind. Microbiol. Biotechnol., vol. 36, pp. 45$51,2009$.

[18] Y.M. Galante, and C. Formantici, "Enzyme applications in detergency and in manufacturing industries", Curr. Org. Chem., vol. 7, pp. 1399-1422, 2003.

[19] R. Campos, A. Kandelbauer, K.H. Robra, A. Cavaco-Paulo, and G. M. Gübitz, "Indigo degradation with purified laccases from Trametes hirsuta and Sclerotium rolfsii", J. Biotechnol., vol. 89, pp. 131-139, 2001.

[20] S. Rodríguez-Couto, and J.L. Toca-Herrera, "Industrial and biotechnological applications of laccases: A review", Biotechnol. Adv., vol. 24, pp. 500-513, 2006.

[21] P.J. Strong, and H. Claus, "Laccase: a review of its past and its future in bioremediation", Crit. Rev. Environ. Sci. Technol., vol. 41, pp. 373-434, 2011.

[22] J.F. Osma, J.L. Toca-Herrera, and S. Rodríguez-Couto, "Cost analysis in laccase production", J. Environ. Manage., vol. 92, pp. 2907-2912, 2011.

[23] P.J. Strong, "Improved laccase production by Trametes pubescens MB89 in distillery wastewaters", Enzyme Res., doi:10.4061/2011/ 379176, 2011.

[24] O. Kirk, T.V. Borchert, and C.C. Fuglsang, "Industrial enzyme applications", Curr. Opin. Biotech., vol. 13, pp. 345-351, 2002.

[25] N.K. Pazarlıglu, M. Sariisik, and A. Telefoncu, "Laccase: production by Trametes versicolor and application to denim washing", Process Biochem., vol. 40, pp. 1673-1678, 2005.

[26] M. Solis-Oba, J. Almendáriz, and G. Viniegra-González. "Biotechnological treatment for colorless denim and textil wastewater treatment with laccase and ABTS", Rev. Int. Contam. Ambient., vol. 24, pp. 5-11, 2008. 
[27] M. Montazer, and A.S. Maryan, "Application of Laccases with Biowashing”, J. Appl. Polym. Sci., vol. 110, pp. 3121-3129, 2008.

Received: July 04, 2011

Revised: December 15,2011

Accepted: December 15, 2011

(c) S. Rodríguez-Couto; Licensee Bentham Open.

This is an open access article licensed under the terms of the Creative Commons Attribution Non-Commercial License (http: //creativecommons.org/licenses/by$\mathrm{nc} / 3.0 /$ ), which permits unrestricted, non-commercial use, distribution and reproduction in any medium, provided the work is properly cited. 